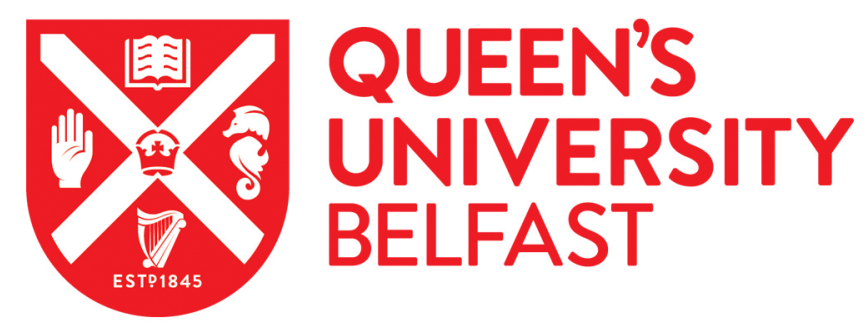

\title{
Towards More Resilience for a Social EU - the Constitutionally Conditioned Internal Market
}

Schiek, D. (2017). Towards More Resilience for a Social EU - the Constitutionally Conditioned Internal Market. European Constitutional Law Review, 13(4), 611-640. https://doi.org/10.1017/S1574019617000311

\author{
Published in: \\ European Constitutional Law Review
}

\section{Document Version:}

Peer reviewed version

Queen's University Belfast - Research Portal:

Link to publication record in Queen's University Belfast Research Portal

Publisher rights

( ) The Authors 2017. This work is made available online in accordance with the publisher's policies. Please refer to any applicable terms of use of the publisher.

\section{General rights}

Copyright for the publications made accessible via the Queen's University Belfast Research Portal is retained by the author(s) and / or other copyright owners and it is a condition of accessing these publications that users recognise and abide by the legal requirements associated with these rights.

Take down policy

The Research Portal is Queen's institutional repository that provides access to Queen's research output. Every effort has been made to ensure that content in the Research Portal does not infringe any person's rights, or applicable UK laws. If you discover content in the Research Portal that you believe breaches copyright or violates any law, please contact openaccess@qub.ac.uk. 


\title{
Towards more resilience for a social $\mathrm{EU}$ - the constitutionally condi- tioned Internal Market
}

\author{
Dagmar Schiek*
}

Abstract: Gap between the EU's normative commitments to socio-economic justice and
the practical workings of its integration project -- Potential for strengthening the Social
EU by recourse to the Charter of Fundamental Rights of the European Union (CFREU) -
CFREU normatively commits EU to a constitutionally conditioned Internal Market -
CFREU curbs property rights and entrepreneurial freedom specifically for the sake of
social rights guarantees - constructive response to legitimacy dilemmas emerging from
cases such as Laval, Viking and AGET Iraklis - reinstating socially embedded constitu-
tionalism at EU levels as an alternative to relegating social integration to national levels.

\section{Introduction}

EU-induced policies in response to the post 2008 global crisis, entailing welfare state entrenchment, flexibilisation of employment relations and de-centralisation of industrial relations have invigorated critique of the demise of "social Europe". ${ }^{1}$ This demise is also viewed as one of the causes of the Union's potential disintegration. Indeed, in the last few years the European Union has failed to improve working and living conditions for the majority of its population, ${ }^{3}$ in spite of a slow upward trend. ${ }^{4}$

\footnotetext{
*Professor of Law, Queen's University Belfast (d.schiek@qub.ac.uk). This paper profited from reflections with other contributors to D. Schiek et al., EU Social and Labour Rights and EU Internal Market Law (Brussels: European Parliament, 2015), specifically Chris Forde, Liz Oliver, Michael Doherty, Kerstin Ahlberg, Consuelo Chacartegui Javega, discussion at the ETUI's 2016 NETLEX conference, feedback by Dora Kostakopoulou (on presenting the full concept at the 2016 CES in Philadelphia) and by Gordon Anthony, as well as the referees and editors. The usual disclaimer applies.

1 I Begg et al., 'EMU and Sustainable Integration', 37 Journal of European Integration (2015), p. 803; H.-J. Bieling, 'Shattered Expectations: The Defeat of European Ambitons of Global Financial Reform', 8 Journal of European Public Policy (2014), p. 34; S. Garben, 'The Constitutional (Im)balance between 'the Market' and 'the Social' in the European Union' 13 EuConst (2017), p. 23; A. Hinarejos, 'Changes to Economic and Monetary Union and their Effect on Social Policy', 32 International Journal of Comparative Labour Law and Industrial Relations (2016), p. 231, U. Neergaard, 'When Poverty comes in at the Door, Love Flies out the Window'. The Influence of Eurozone Reforms upon the Social Dimension of the EU - and Vice Versa?', 7 European Labour Law Journal, (2016), 168-204.

2 See, for example, S. Deakin, 'Brexit, Labour Rights and Migration: Why Wisbech Matters to Brussels', 17 German Law Journal (2016), 13-20.

3 EUROFUND, Experiencing the economic crisis in the EU: changes in living standards, deprivation and trust (European Foundation for the Improvement of Living and Working Conditions, 2015).

${ }^{4}$ D. Schraad-Tischler and Ch. Schiller, Social Justice in the EU - Index Report (Düsseldorf: Bertelsmann Foundation, 2016).
} 
This contradicts the European Union's (EU) normative aspirations. These hark back to its origins as European Economic Community (EEC, 1957), which pursued the Common Market in order to promote an "accelerated raising of the standard of living", ${ }^{5}$ relying on the intensification of social interaction as a base for enhanced economic and ultimately human cooperation. ${ }^{6}$ Today's EU continues to pursue these aims alongside an expanded catalogue of objectives: established for the sake of 'elimination of barriers that divide Europe' (Preamble TEU) and the 'promotion of peace (...) and the well-being of (...) peoples' (Article 3 (1) TEU), it aims at an ever closer union of peoples, not of states, underlining that the Union serves societies, not polities. Its goals combine freedom and solidarity with ecological and socio-economic sustainability (Article 3 TEU). While committed to establishing an internal market (Article 26 TFEU), the Treaty envisages the social market economy (Article 3 (3) TEU) among others as an instrument for continuing improvement of living standards EU. If integration of markets is legitimised by the overarching aim of promoting economic and social progress (Article 3 (1) TEU), the EU's practical failure at improving working and living standards for its citizens epitomises a normative crisis with constitutional dimensions.

This article is part of a larger legal-constitutional academic project developing ways to close the gap between the EU's normative commitments to socio-economic justice and the practical workings of its integration project. If the EU is to regain social legitimacy while continuing economic integration, it must pursue economic and social integration at European and national levels as an interconnected endeavour. Accordingly, law and politics of social integration ("social Europe") will have to attain a veritable EU dimension. To realise this aim, EU level legislation, non-legislative governance and adjudication will have to change, and those changes will have to address shortcomings in the Internal Market ${ }^{8}$ as well as in the Economic and Monetary Union. ${ }^{9}$

\footnotetext{
${ }^{5}$ Article 2 EEC read: "The Community shall have as its task, by establishing a common market and progressively approximating the economic policies of member states, to promote throughout the community a harmonious development of economic activities, a continuous and balanced expansion, an increase in stability, an accelerated raising of the standard of living and closer relations between the states belonging to it".

${ }^{6}$ See also D. Chalmers and S. Trotter, 'Fundamental Rights and Legal Wrongs: The Two Sides of the Same EU Coin', 22 European Law Journal (2016), 9-39, with a more pessimistic assessment.

${ }^{7}$ For a more expansive explanation see D. Schiek, 'Re-embedding economic and social constitutionalism: normative perspectives for the EU', in D. Schiek et al (eds) European Economic and Social Constitutionalism after the Treaty of Lisbon (Cambridge University Press, 2011), p. 17. ${ }^{8}$ Despite the recent dominance of the reflections of the global economic crisis in the $€$-zone economy, the Internal Market's legal frame remains decisive for national and EU level realisation of "social Europe" (see on this Schiek et al fn *, see also Deakin $\mathrm{fn} 2$ ), and continues to demand academic attention (for a recent overview from political science perspectives see M. Blauberger and S.K. Schmitt, 'The European Court of Justice and its political impact' 40 West European Politics (2017), p. 907).

9 See on recent critique of the negative impact of EMU governance on social integration in the EU Begg, Hinarejos and Neergaard (as cited in $\mathrm{fn} 1$ ); on the related critique of de-legalisation in the framework of the crisis M. Everson and Ch. Joerges, 'Reconfiguring the Politics-Law Relationship in the Integration Project through Conflicts-Law Constitutionalism', 18 European Law Journal, (2012), p. 644; N. Scicluna, European Union Constitutionalism in Crisis (New York: Routledge, 2014); C. Kilpatrick, 'On the Rule of Law and Economic Emergency: The Degradation of Basic Legal Values in Europe's Bailouts', 35 Oxford Journal of Legal Studies (2015), p. 325.
} 
This article focuses on the changes required in the Court's case law, if the EU is to achieve an EU level dimension of "social Europe" as an intrinsic element of its Internal Market. It argues that after the EU Charter of Fundamental Rights (CFREU), the EU Internal Market is constitutionally conditioned by social rights as well as by the economic rights guaranteed in the Charter. Instead of conceptualising the relation between those two types of rights as one of contradiction, the constitutionally conditioned Internal Market promotes economic integration, defined as the merging of markets at a transnational level' while respecting and promoting the entire range of CFREU rights, thus also promoting social integration, which enables citizens to govern their own lives by ensuring sufficient means for surviving and partaking in their polity's cultural and social achievements. ${ }^{10}$ This approach challenges two alternatives propositions: that the EU is predominantly determined by an economic constitution, ${ }^{11}$ and that the EU constitution is wholly neutral towards different models of economic and social integration. ${ }^{12}$ While the argument moves deliberately within the framework of the existing Treaties, ${ }^{13}$ this is not intended to cast doubt on the value of Treaty reform.

The article first presents the conventional perception of the Internal Market's challenges for "social Europe" as a three-pronged conceptual matrix of conflicts and tensions. Subsequently, the concept of constitutionally conditioning as an alternative to juxtaposing EU economic integration and social policy is developed, with a focus on rights guarantees contained in the CFREU. In an ultimate step, the practical potential of the concept is demonstrated by devising an alternative path for judicial decisions taken in the Court's so-called Laval quartet and the recent AGET Iraklis case.

\section{The EU Internal Market Challenges and social rights}

\section{A conceptual matrix}

The critique of the EU Internal Market's impact on social policy seems deceptively simple at first sight: constitutionalisation of economic freedoms and competition law initiates a vicious circle: litigation by individual parties or the EU Commission ${ }^{14}$ may result in judicial findings of inapplicability of social policy measures at national level on grounds of an infringement of EU economic freedoms or competition law. Replacing any such social policy measures at EU levels is encumbered by the complexity of achieving political agreement in a Union of nearly 30 Member States, resulting in a structural imbal-

\footnotetext{
${ }^{10}$ See D. Schiek, Economic and Social Integration. The Challenge for EU Constitutional Law (Edward Elgar, 2012), p. 13-49

${ }^{11}$ E.g. K. Tuori, European Constitutionalism (Cambridge: Cambridge University Press, 2015), p.146-330.

${ }^{12}$ E.g. C. Kaupa, The Pluralist Character of the European economic constitution (Hart 2016).

${ }^{13}$ This is shared by H. Brunkhorst, 'Auswege aus der technokratischen Falle? Die unbeachtete Wirtschaftsverfassung Europas', 42 Leviathan, (2014), p. 508; see also (with a focus on legislation) C Barnard and G de Baere, Towards a European Social Union (Euroforum, 2014). ${ }^{14}$ References and EU Commission infringement actions are the two most frequent procedures before the Court of Justice, comprising 458 references and 59 direct actions in 2016 (see Court of Justice of the European Union, Annual Report 2016, Luxembourg 2017, pp. 87-101).
} 
ance in favour of economic integration ${ }^{15}$ and the incapacity of the EU to become a social market economy.

Upon closer inspection, the constitutionalisation of transnational economic integration through direct effect and supremacy of economic freedoms and competition law requires a complex analysis in three dimensions. First, market constitutionalisation can be presented as conflicts between national and EU competences for regulation and/or adjudication. Secondly, adjudication of (social) policy is perceived as a potentially illegitimate limitation of the democratic legislative process. Thirdly, there is a potential tension in substance between the Internal Market and social policy. All three dimensions influence each other as visualised in the conceptual matrix portrayed below, and further discussed in the remainder of this section.

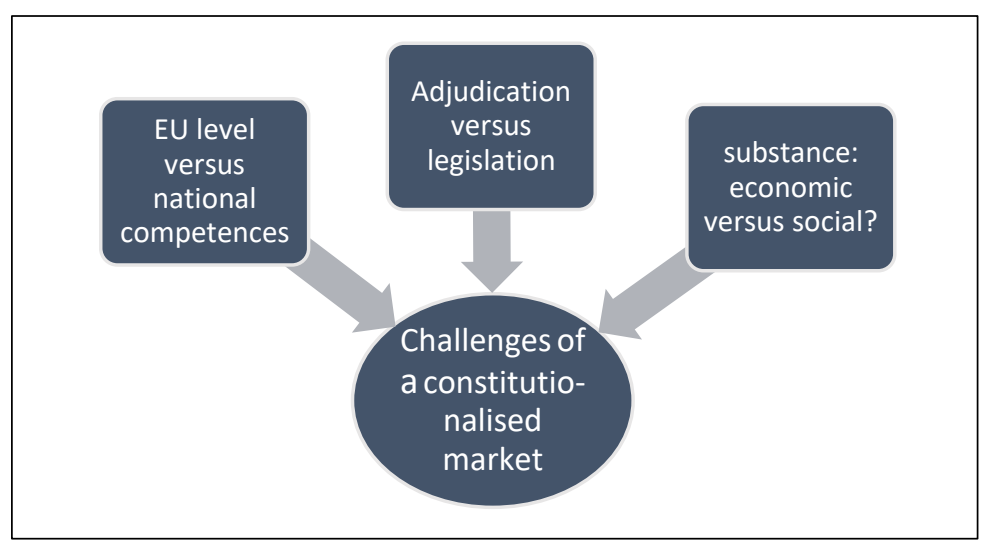

\section{EU level versus national competences: the demise and resurrection of em- bedded liberalism}

There is little doubt that direct effect and supremacy of the legal guarantees of economic freedoms and competition law effectively constitutionalised the Internal Market at EU level. ${ }^{17}$ Decisions on whether and in how far to implement the four freedoms have been moved from the national to the supranational level. Nevertheless, the founders of the European Economic Community (EEC, 1957) did not perceive of the economic integration as isolated from national law and policy. Economic liberalisation at Community level was coupled with national autonomy in the field of social policy. To achieve its overall aims, the EEC depended on sufficient degrees of social integration at national levels, while not offering any legal guarantee to this effect.

\footnotetext{
${ }^{15}$ S. Garben, supra fn. 1, at p. 51, concurring with Scharpf and Joerges.

${ }^{16}$ F. W Scharpf 'The asymmetry of European integration, or why the EU cannot be a "social market economy"'"', 8 Socio-Economic Review (2010), p. 211; challenged by D. Damjanovic, ('The EU market rules as social market rules: Why the EU can be a social market economy' 50 Common Market Law Review (2013), p. 1685).

${ }^{17}$ M. Poiares Maduro, We The Court. The European Court of Justice and the European Economic Constitution (Oxford \& Portland: Hart, 1998); A. Hatje, 'The Economic Constitution within the Internal Market', in A Bogdandy and J Bast (eds), Principles of European Constitutional Law (Beck \& Hart, 2010), p. 589.
} 
This model was congruent with "embedded liberalism", as empirically observed and normatively envisioned by John Ruggie: ${ }^{18}$ liberalisation of markets beyond national borders should be contained by national "intervention"19 aiming, among others, at "social protection" ${ }^{20}$ Ruggie's original model presupposed state cooperation with the aim of maintaining the potential for intervention while enabling global trade through agreeing on legal instruments. Changes in international economic law and politics initiated the demise of embedded liberalism as a global model. ${ }^{21}$ Accordingly, Abdelal and Ruggie now demand that international organisations should not promote capital liberalisation, but continue to burden national governments with the responsibility of ensuring the social legitimacy of global capitalism. ${ }^{22}$

Constitutionalisation of the EU level rules on the Internal Market challenged embedded liberalism EU style: ${ }^{23}$ once the Court had established a broad notion of the economic freedoms, according to which free movement of goods, freedom of establishment and freedom to provide services could be restricted by any rule (or practice) making economic activities across a border less economically attractive, swathes of national law and policy potentially qualified as restrictions. The economic freedoms could be read as providing scope for Member States to fulfil the national part of the embedded liberalism compromise. ${ }^{24}$ However, the Court of Justice required that national law and policy are justified, while the deregulatory thrust of the economic freedoms had to be accepted without any justification. As far as embedded liberalism was practiced within the $\mathrm{EU}$, it lost its equilibrium through this case law.

Parts of the literature decry the demise of embedded liberalism, and devise ways how to re-establish its regime. For example, Mulder ${ }^{25}$ promotes responsive adjudication, which should safeguard national social policy against overly intrusive ECJ case law promoting economic integration. This is based on the conceptual doubt of whether links between citizens beyond national borders are sufficiently close to legitimise redistribu-

${ }^{18}$ See J.G. Ruggie 'International Regimes, Transactions, and Change: Embedded Liberalism in the Postwar Economic Order' 36 International Organisation (1982), p. 379.

${ }^{21}$ These comprise the break-down of the Bretton Woods compromise through abandoning a global regime of currency coordination regulation of currency relations (see for a brief summary with further references Schiek, supra note 10, p. 16-17), on the contribution of EU level economic integration to dismantling the preconditions of the practical emanation of embedded liberalism by the EEC see Ch. Hermann, 'Crisis, structural reform and the dismantling of the European Social Model', 35 Economic and Industrial Democracy (2014), p. 51.

${ }^{22}$ R. Abdelal and J.G. Ruggie 'The Principles of Embedded Liberalism: Social Legitimacy and Global Capitalism' in D. Moss and J Cisernino (eds) New Perspectives on Regulation (The Tobin Project 2009), p.151, at p. 157, 159.

${ }^{23}$ See St. Giubboni, Social Rights and Market Freedom in the European Constitution. A Labour Law Perspective (Cambridge University Press, 2006).

${ }^{24}$ See D Schiek, 'The European Social Model and the Services Directive', in U. Neergaard, R Nielsen and L Roseberry (eds) The Services Directive - Consequences for the Welfare State and the European Social Model (DJØF Publishing, 2008), p. 25.

${ }^{25}$ See J. Mulder, 'Responsive Adjudication and the 'Social Legitimacy' of the Internal Market', 22 European Law Journal, (2016), p. 597. 
tion. ${ }^{26}$ Inevitably Member States and the EU itself share responsibility for the overall social legitimacy of the European Union as a composite polity. Thus, the social compromises found at national levels deserve protection until such time that a European level compromise has been established. ${ }^{27}$ However, relocating the responsibility for social policy to Member States alone would also mean to reinforce the decoupling of economic integration at EU level from social integration at national levels. That same decoupling has been identified as a risk for maintaining the European Social Model early in the $2000 \mathrm{~s}^{28}$ Thus, it is highly unlikely that re-instating embedded liberalism, as it was observed in the 1980s, in a more elaborate form is suitable for re-establishing the EU's social legitimacy in the $21^{\text {st }}$ century.

The Achilles' Heel of the remaining defenders of the constitutionalised Internal Market in the absence of EU level constitutional guarantees of social rights is the declining capacity of nation states to provide the complementary social policy needed to maintain the social legitimacy of economic integration. It has been argued that the constitutionalised Internal Market itself, and even more so Economic and Monetary Union, endanger this very capacity. ${ }^{29}$ The social embedding of EU economic integration cannot be provided by nation states alone. This consideration gains relevance ever more with the increasing divergence of economies and societies in EU Member States which again is enhanced by EU enlargements and the operation of Economic and Monetary Union. States governing a weaker economy, having lower tax (or other state) revenue and limited regulatory power would not be able to guarantee levels of social integration that would be sufficient to maintain the EU's aim of constituting a transnational economy in socially responsible ways. ${ }^{30}$ Also, European economic integration going beyond mere state cooperation, as envisaged by traditional international law, is now in operation for more than 60 years. This has engendered truly transnational economic structures, in which national borders become increasingly irrelevant for business activity. This again means that business is beyond the reach of national social law and policy because the Internal Market increases the ease with which it moves from one regulatory regime to another. As a consequence, if the social embedding of the EU Internal Market is to succeed, it needs to be established at the EU level, where this market is constitutionalised.

\section{Adjudication versus legislation - a limited perspective}

The critique of the EU's imbalanced integration between economic and social realms also constitutes a critique of its Court and its legitimate role. A focus on the dispropor-

\footnotetext{
${ }^{26}$ R. Bellamy and A. Waele, 'Political legitimacy and European monetary union: contracts, constitutionalism and the normative logic of two-level games', 22 Journal of European Public Policy, (2015), 257-74, similarly Garben, op. cit. fn. 1, p. 27, and Joerges, supra fn. 34.

${ }^{27}$ D Schiek, supra fn. 24.

${ }^{28}$ Scharpf, 'The European Social Model: Coping with Challenges of Diversity' 40 Journal of Common Market Studies (2002), p. 645.

${ }^{29}$ D. Ashiagbor, 'Unravelling the Embedded Liberal Bargain: Labour and Social Welfare Law in the Context of EU Market Integration' 19 European Law Journal (2013), p. 303; S Giubboni, 'Social Rights and Market Freedom in the European Constitution: A Reappraisal', in K. Tuori and S. Sankari (eds) The Many Constitutions of Europe, (Ashgate, 2010), p. 241, D. Schiek, supra n. 7, M. Höpner and A. Schäfer, 'A New Phase of European Integration: Organised Capitalism in PostRicardian Europe', 33 West European Politics (2010), p. 344.

${ }^{30}$ See for more detail D. Schiek (2012), supra fn. 10, p. 230-232.
} 
tionate power of judges in adjudicating the Internal Market ${ }^{31}$ has led some authors to suggest that direct effect and supremacy of EU law should no longer be recognised ${ }^{32}$ or that there should be an EU level mechanism for Member States to challenge contentious rulings by the Court of Justice. ${ }^{33}$ While some of these authors demand protecting the Member States' authority (including for social policy) from the ECJ's adjudication, the prioritisation of legislation over adjudication is not necessarily linked to a preference for national social policymaking. For example, Grimm promotes a mixed model, demanding that the economic freedoms and competition law are removed from the EU Treaties, to allow changes through the ordinary EU legislative process. ${ }^{35}$ This proposal aims at empowering democratic process at national as well as at EU levels, hoping that this will result in meaningful social integration measures. Vouching for EU level social policy beyond the judicial arena, Sacha Garben promotes changing the EU Treaties to reduce the economic freedoms to mere bans of discrimination, allowing for EU level legislation re-balancing "the market" and "the social".

These positions question the current state of the EU as a constitutional democracy, where legislators at national and EU levels are bound by judicially enforceable rights, protected by a strong constitutional court and not open for amendment by simple parliamentary democracy. Constitutional democracy in European national constitutions was first motivated by the aim to avoid a repetition of the Holocaust's atrocities, and later by the human-rights deficits behind the proverbial iron curtain. ${ }^{37}$ The classical justification of constitutional democracy developed by Ely for nation states ${ }^{38}$ rests on the need to safeguard the interests of minorities which will be at a structural disadvantage in a majoritarian democracy.

This justification is enhanced through the increasing trans-nationalisation of economies and societies which the EU Internal Market aims to engender. The diversity of a polity such as the EU with nearly 30 Member States does not offer a dense web of social rela-

${ }^{31}$ F. Scharpf, 'Monetary Union, Fiscal Crisis and the Pre-emption of Democracy', 9 Zeitschrift für Staats- und Europawissenschaften (2011), p. 163-98, M. Höpner and A. Schäfer, supra n. 29.

${ }^{32}$ Ch. Joerges, 'Rethinking European Law's Supremacy: A Plea for a Supranational Conflict of Laws, in', in B. Kohler-Koch and B. Rittberger (eds) Debating the Democratic Legitimacy of the European Union, (Ranham : Rownan \& Littlefield, 2007), p. 311, M. Dawson and F. de Witte, 'From Balance to Conflict: A New Constitution for the EU', 22 European Law Journal (2016), p. 204.

${ }^{33}$ F. Scharpf, 'Legitimacy in the Multilevel European Polity', 1 European Political Science Review, (2009), p. 173.

${ }^{34}$ This is implicitly linked to the assumption that EU citizens would not develop sufficient levels of transnational solidarity to construe an EU level social model (Ch. Joerges 'Integration through law and the crisis of law in Europe's emergency' in D. Chalmers et al (eds) The End of the Eurocrat's Dream (Cambridge University Press, 2016), p. 416, at p. 440).

${ }^{35}$ D. Grimm, Europa ja - aber welches? (Beck, 2016), chapters I, II and IV, for a critical assessment see NN (Editorial Comments) 'A way to win back support for the European project?' 54 CMLR (2017), p. 1.

${ }^{36}$ S. Garben, supra fn. 1.

${ }^{37}$ A Stone Sweet, 'The European Court of Justice', in P. Craig and G de Búrca (eds) The Evolution of EU Law ( Oxford University Press, 2011), p. 121.

${ }^{38}$ J.H. Ely, Democracy and Distrust. A Constitutional Theory of Judicial Review (Harvard University Press, 1980). 
tions that could mitigate the exclusionary tendencies of majoritarian democracies, adding a further argument in favour of juridification. Jo Weiler was one of the first to submit that national legislators and constitutional adjudication may well neglect the interests of non-national EU citizens necessitating specific protection by the European Court of Justice. ${ }^{39}$ Judicial control as a complementary way of governance retains a significant role in protecting citizens against national bias as well as majoritarian bias at EU level.

In the EU, whose constitutionalised Internal Market enables transnational market exchange defying national legislation, citizens also need protection against regulatory power by economic actors. While a treatise of the multiple emanations of rulemaking by commercial and non-commercial non-state actors are beyond the scope of this article ${ }^{40}$ it is worthwhile underlining the potential offered by judicial rights protection to challenge rules made by non-state actors. The ECJ's doctrine of horizontal effects of economic freedoms entails this potential, and can thus enhance the constitutional legitimacy of the Internal Market.

Recognising a strong role for a constitutional court also necessitates recognising its political role. Adjudication, especially constitutional adjudication, of necessity goes beyond deriving the one possible answer to a legal question from the positive law, ${ }^{41}$ even though it rests on legal hermeneutics instead of parliamentary discourse. This is reflected in the practice of many courts - continental and otherwise - to allow for minority opinions. Judicial discourse can change, is open to constant challenge, and change should not be viewed as a weakness. On the contrary, the deliberative character of constitutional adjudication $^{42}$ is a precondition for its legitimacy as one element of dem-

\footnotetext{
39 J. Weiler, 'In defence of the status quo: Europe's constitutional Sonderweg', in J. Weiler and
} M. Wind (eds) European Constitutionalism beyond the State (Cambridge University Press 2003), p. 7. This is now referred to as the "Argument from Transnational Effects" (A. Somek, 'The Argument from Transnational Effects I: Representing Outsiders through Freedom of Movement', 16 European Law Journal (2010), p. 315; J. Mulder, supra fn. 25, at 600-620, and harks back to classical expositions of the Court's development of EU Internal Market Law (e.g. M Poaires Maduro, We the Court (Hart Publishing, 1998).

${ }^{40}$ See for a summary of my deliberations on this so far D. Schiek, 'A constitution of social governance for the European Union', in N. Ferreira and D. Kostakopoulou (eds) The Human Face of the European Union (Cambridge: Cambridge University Press, 2016), p. 17,

${ }^{41}$ This is a consequence of the principled indeterminacy of any law. Notwithstanding profound differences in detail, there is agreement in so far between linguists, positivists and different jurisprudential schools. Linguists agree on the existence of imbued meaning and the necessity of drawing on circumstantial knowledge when understanding textual language, which is also the starting point of critical discourse analysis (Th. van Leeuwen, 'Discourse as Recontextualisation of Social Practice: A Guide', in R. Wodak and M. Meyer (eds) Methods of Critical Discourse Analysis, (Sage, 2009), p. 144, at 147). Positivist legal theorists acknowledge the open texture of law as described above ) H.L.A. Hart, The Concept of Law, with a postscript by Penelope Bulloch and Joseph Raz (Oxford University Press, $2^{\text {nd }}$ ed 1997), p. 118, 123-126), including "uncertainty" (Hart) or judicial discretion and choice (D. Leczykiewicz, 'Why Do the European Court of Justice Judges Need Legal Concepts?', 14 European Law Journal (2008), p. 773, at 774); from the perspective of a former constitutional court judge see Grimm, supra fn 35 , at p. 8.

${ }^{42}$ On models for judicial deliberation see O. Gerstenberg 'Negative/positive constitutionalism, "fair balance," and the problem of justiciability' (10) Int J Const Law (2012), p. 904; see also B. de Witte, 'Democratic Adjudication in Europe - How Can the European Court of Justice be Responsive to the Citizen?' in M. Dougan, N Nic Shuibhne and E Spaventa (eds) Empowerment and Disempowerment of the European Citizen (Hart Publishing, 2012). 
ocratic governance in complex polities and societies, and indeed of the legitimacy of judicial governance in the EU polity. ${ }^{43}$ Therefore, any court cannot but be a political and social actor in deciding which aspects of an indeterminate norm it allows to prevail. ${ }^{44}$

Accordingly, the Court's case law will need to be challenged politically as well as academically. The conditions for the case law to change include an attentive public sphere which takes note of the Court's direction and subjects it to the scrutiny of public discourse, thus enabling the Court to become responsive to the citizenry. This discourse must respect the judicial function, which is to interpret the positive law, and bring it into line with the requirements of justice. Academic legal discourse is an important element of this scrutiny. It is in this spirit that an alternative path for the Court to follow is developed sub III and IV.

\section{Substance: economic versus social?}

The substantive prong of the critique sketched above ${ }^{45}$ focusses on the bias of the EU integration project towards a specific economic model, with structural bias against sustaining social values at EU, transnational or national levels. This critique focusses on the ECJ's jurisprudence on economic freedoms and competition law, the provisions forming the core of the EU's economic constitution.

Briefly summarised, ${ }^{46}$ the critique asserts that the Court of Justice, by reading the economic freedoms as bans on restricting transnational economic activity as well as transnational trade, classifies any measure rendering the exercise of one of the economic freedoms in another Member State less attractive than the exercise of the same freedom at a mere national level as a restriction of an economic freedom. A restriction does not necessarily constitute an infringement, as it can be justified. While defining the substantive reach of economic freedoms ever more widely, the Court has also expanded the options to justify a restriction beyond those positively enshrined in the Treaty. Any mandatory requirement in the public interest can justify a restriction, as long as the restriction is proportionate to achieve this aim. The jurisprudence on the economic freedoms has wavered between merely enforcing economic freedoms across borders and promoting economic liberty independently of its trans-border character. Recent case law has shown a tendency to become more lenient on the requirement of transnationality, for example in assuming a limitation of cross-border trade in goods if the use of a good is restricted, for example through a ban of using watercrafts on noncommercial waterways or towing trailers behind motorcycles. ${ }^{47}$ If the Court defends not only cross-border economic activity, but the use of market freedoms more widely, it

\footnotetext{
${ }^{43}$ See on the term Schiek (2012), supra fn. 10, p. 217, 235-237.

${ }^{44}$ For the European Court of Justice, see for example A. Stone Sweet, 'The European Court of Justice and the judicialization of EU governance', 5 Living Reviews in European Governance, (2010), at p. 7-9; see also J. Bengoetxea et al, 'Integration and Integrity in the Legal Reasoning of the European Court of Justice', in G. de Burca and J. Weiler (eds) The European Court of Justice, (Oxford University Press, 2001), p. 43, who question whether a clear line between law and politics really exists, as the critique of the Court's activism asserts.

${ }^{45}$ Text surrounding fn. 15 to 17.

${ }^{46}$ For more detail see K. Tuori (2015), supra fn. 11, p.146-330; Schiek, supra fn. 10, p. 79-112.

${ }^{47}$ ECJ 4 June 2009 C-142/05 Åklagaren v Percey Mickelsson (Watercrafts), 10 February 2009 C11/05 Com v Italy (Trailers).
} 
may be accused of lending constitutional authority to one particular approach to economic policy, often portrayed as the basis of ordo-liberal thought. ${ }^{48}$ A wide scope of application for economic freedoms bases the EU economic constitution on economic liberties for entrepreneurs. This narrow perspective is arguably contested within the Treaties, which provide for planned production and price regimes in the agricultural policy, protect EU internal production through a common customs tariff and promote substantive investment through the common transport policy as well as industrial policies.

In the field of EU competition law, the Court shares authority with the EU Commission as EU competition authority. The Commission's official role here comprises issuing guidelines, and enforcing competition rules such as the prohibition of cartels, of the abuse of a dominant market position or of state aid. The Court and the national courts can be seized not only to challenge the actions of national and EU competition authorities, but also in order to invalidate legislation and challenge behaviour of non-state actors deemed, by ECJ standards, to be economic actors. Again, the competition rules can be interpreted as mainly aimed at protecting the Internal Market from practices of private economic actors; or more principled as ordaining competitive markets as a principle of organising societies. The Court and the EU Commission have charted a contradictory course in both regards, and this course still awaits a thorough theorisation from critical perspectives on economic and social integration. Accordingly, the principles of the constitutionally conditioned Internal Market will be developed in relation to economic freedoms below, leaving a thorough discussion of EU competition law for a different occasion.

The Court's prevailing interpretation of economic freedoms veers towards an economic constitution prioritising the individual rights of economic actors. By placing justifications in the public interest systematically on the proverbial back foot, it also is intrusive on social integration measures. While the process may lead to accepting national social policy choices, more frequently these are invalidated or stymied. ${ }^{51}$ Case law on econom-

${ }^{48}$ See Ch. Joerges, supra fn34, p 419-421; for an extended analysis of ordo-liberal thinking see Tuori, supra fn. 46, p. 143-148.

${ }^{49}$ See Schiek (2012), supra note 10, p. 23, on principles countering a constitution only based on economic liberties for entrepreneurs. For a recent exposition of the economic neutrality of the Treaties see Kaupa (2016), supra fn.12, see also Tuori, supra fn. 46, at p. 162-185.

${ }^{50}$ See on the lack of a critical alternative to ordoliberal thought in this area Tuori, supra fn. 46, at p. 171-175, for an early discussion of the interaction of free movement and competition with some coverage of social policy see J Bacquero Cruz, Between Competition and Free Movement (Hart, 2002), partial coverage on social services of general interest by U. Neergaard et al (eds) Social Services of General Interest in Europe, (Springer, 2013), on the higher education sector see A. Gideon, Higher Education Institutions in the EU: Between Competition and Public Service (Springer, 2017), some aspects of competition law are also covered in Schiek et al (2015) supra fn *, p. 90-91.

${ }^{51}$ The imbalance is not quite as dramatic as portrayed by authors such as Scharpf, Joerges, Höppner and Schaefer though - see for analyses of swathes of case law Schiek (2012), supra fn. 21, p. 113-214 (content analysis of all 144 Grand Chamber rulings on the EU's economic and social constitution between 2004 and 2011 from socio-legal perspectives), D. Sindbjerg Martinsen, An ever more powerful Court? The Political Constraints of Legal Integration in the 
ic freedoms is not limited to controlling legislation. Instead, direct horizontal effect of economic freedoms also allows judicial review of market actors' rules.

Considering the current case law from a legal-realist perspective, Tuori stresses that EU Internal Market law constitutes a strong economic constitution, which is co-original with the European integration project. ${ }^{52}$ This seems to render other constitutional layers of the EU edifice, including the social constitution, less powerful. Kilpatrick and de Witte even portray the economic and the social constitution as mutually exclusive, suggesting that one will be victorious over the other eventually. ${ }^{53}$ For some authors, the layered presentation of the EU's constitution constitutes the starting point for a critique of EU law and policies, predicting doom for the European integration project because it fails to achieve its promises of improving Europe's societies. ${ }^{54}$ These strands of substantive critique, in all their diversity, juxtapose the Internal Market as part of the EU's economic constitution to the demands of other constitutional principles at EU level.

This juxtaposition risks overlooking contradictions and opportunities to drive forward an interpretation of internal market law that would support the social embedding of EU constitutional law not only through national legislation, but at the EU level itself.

\section{Beyond the impasse}

In order to overcome the EU's normative impasse as sketched initially it is necessary to move beyond juxtaposing the EU's economic constitution on the one hand and its social values on the other. This substantive starting point will invite confusing the protection of Member States sovereignty with the pursuit of social policy within the European Union. This again neglects the potential for protecting and promoting social rights at EU level, which again is a precondition of overcoming the stated imbalance between the EU's economic and social constitution.

The Treaties and their predecessors themselves have never merely juxtaposed pure economic integration with other forms of integration. Instead, they combine free movement of goods and services, as well as competition rules with guarantees of free movement of persons and capital. By guaranteeing free movement of persons, especially of workers, under the condition of equal treatment alongside economic freedoms for producers and service providers, the European Union's unique socio-economic model of regional integration holds out the promise of participative inclusion.

Accordingly, the much criticised ECJ case law also is inconsistent. For example, horizontal effect of economic freedoms has contradictory effects: it may protect weaker parties such as free-moving workers from discrimination by employers, but may also be utilised

European Union (Oxford University Press, 2015), screening 1025 ECJ rulings on social policy since 1959 while analysing impact of case law on social policy from political science perspectives.

${ }^{52}$ Tuori (2015), supra fn 11.

${ }^{53}$ C. Kilpatrick and B. de Witte Social Rights in Times of Crisis in the Eurozone: The Role of Fundamental Rights Challenges, (Florence: European University Institute, 2014).

${ }^{54}$ D. Ashiagbor, supra n. 29; St. Evju (ed) Cross-Border Services, Posting of Workers and Multilevel Governance, (Oslo: University of Oslo, 2013); Ch. Hermann, supra, fn. 21, M. Höpner and A. Schäfer, supra n. 29, F. W Scharpf, 'Das Dilemma der supranationalen Demokratie in Europa', 43 Leviathan (2015), p. 11. 
by those in a position of economic power, such as the members of the Swedish building sector employers' association, against the claims of workers posted to Sweden. ${ }^{55}$

The ambiguous character of EU constitutional law does not merely suggest that the EU constitution refrains from determining a certain model of economic integration. ${ }^{56}$ Going beyond this, it is necessary and possible to derive a normative frame supporting rather than obstructing the social embedding of market constitutionalisation at EU level. ${ }^{57}$ The concept of constitutionally conditioning the Internal Market ensures that constitutionalisation through rights guarantees can provide a basis for strengthening "social Europe". When the ECJ's case law eventually changes to embrace this concept, this will also facilitate legislative projects such as implementing the European Pillar of Social Rights. ${ }^{58}$

\section{Constitutionally conditioned Internal Market: enhancing social rights effectively}

In developing the Constitutionally conditioned Internal Market, this section first introduces the concept, and subsequently argues that a purposive interpretation of the CFREU points to constitutional conditioning as its normative demand.

\section{Constitutional conditioning - the concept}

The notion of a constitutionally conditioned market is inspired by the Polanyian idea that markets, if based on unlimited liberties, risk endangering society and thus their own basis. ${ }^{59}$ Polanyi predicted that societies would eventually produce countermovements to contain the destructive tendencies of pure egotism, ${ }^{60}$ describing this process by the term "embedding", whose often criticised imprecision ${ }^{61}$ invited reinterpretation. Ruggie's embedded liberalism ${ }^{62}$ constituted such a re-interpretation, in that it proposed embedding global economic integration through national institutions. The implicit decoupling of trade liberalisation (at international levels) from social integration (at national levels) constitutes this model's central weakness.

Sharing the principle that trade is conditional upon respecting social constitutions, the concept of "constitutional conditioning" proposes to overcome this weakness by demanding a re-embedding of the EU Internal Market through legal guarantees at EU lev-

\footnotetext{
${ }^{55}$ On this constellation see sub IV 1.

${ }^{56}$ See Kaupa (2016), supra fn. 12.

${ }^{57}$ Schiek, supra fn. 7.

${ }^{58}$ Proposal for a (sic) Interinstitutional Proclamation for a European Pillar of Social Rights of 26 April 2016, COM (2017) 251 final

${ }^{59}$ The Great Transformation (Beacon Press, 1957 (first published 1944), for a revival for positive visions of EU integration see J. A. Caporaso and S. Tarrow, 'Polanyi in Brussels: Supranational Institutions and the Transitional Embedding of Markets', 63 International Organization, (2009), p. 593; for more critical views see Ch. Joerges and J. Falke (eds) Karl Polanyi, Globalisation and the Potential of Law in Transitional Markets (Hart Publishing 2011).

${ }^{60} \mathrm{Ch}$. Joerges, Between Jürgen Habermas and Carl Schmitt: Flaws old and new in the project of European Integration (Hertie School of Governance, 2013).

${ }^{61}$ G. Hodgson, 'Karl Polanyi on economy and society: a critical analysis of core concepts', Review of Social Economy, 2016, 1-25.

62 See above text to nn 18-22.
} 
els. For a society to survive, competitiveness is not sufficient. Competitiveness does nothing to engender cooperation, which is the vital basis for societies. Nevertheless, markets are not only social constructs, but also constitute spheres of interaction between people. Such market cooperation harbours the potential to further social cohesion, as has been recognised by the EEC's founding idea of utilising market-based cooperation to gradually bring the people of Europe closer together. Hearkening back to European classics of political sociology, the dichotomy between Weberian and Durkheimian (Parsonian) approaches ${ }^{63}$ allows theorising the conditions of social cohesion through market integration in the EU: the former demands a certain degree of homogeneity for societies to integrate, while the latter relies on solidarity derived from performing distinct roles in diverse societies. Only the latter version allows a positive vision of "unity in diversity", which is the EU's motto.

However, solidarity based on a market-based division of labour is not an automatic process. It requires a civilising frame, ${ }^{64}$ embedding economically motivated interaction and thus facilitating social integration. Such a frame can be engendered through rules and ultimately law. ${ }^{65}$ Comprehensive notions of human rights are well suited to function as a civilising frame for markets. They safeguard the ability of citizens to self-govern their lives, which of course pre-supposes cooperation with and respecting the rights of others. This means that human rights should offer protection against overbearing regulation by states or the European Union as well as by overbearing private actors. ${ }^{66}$ Read in this way, human rights become preconditions for markets, constituting them, and their protection cannot be interpreted as a limitation or restriction of markets.

The EU integration project, based on the progressive expansion of economic integration as an instrument to achieve an ever closer union of peoples, can only remain politically sustainable if its Internal Market is embedded in such a civilising frame. The next section argues that the EU, by accepting the binding legal character of the CFREU, has also accepted that the Internal Market is constitutionally conditioned, particularly by social rights. ${ }^{67}$

\footnotetext{
63 J. Habermas, Between Facts and Norms (Polity Press, 1996), p. 66-78; H. Silver, 'The Social Integration of Germany since Unification', 28 German Politics and Society, (2010), p. 165; H-J Trenz, 'Social Theory and European Integration', in A Favell and V Guiraudon (eds) Sociology of the European Union (Palgrave MacMillan, 2011), p. 193.

${ }^{64}$ J. Kappeler, B. Schütz and D. Tamesberger, 'From free to civilized trade: a European perspective', 74 Review of Social Economy, (2016), p. 320-28.

${ }^{65}$ L. L Fuller, 'Law as an Instrument of Social Control and Law as a Facilitation of Human Interaction', 89 Brigham Young University Law Review, (1975), 89-96.

${ }^{66}$ See already D Schiek, 'Fundamental Rights Jurisprudence between Member States' Prerogatives and Citizens' Autonomy', in H Micklitz and B de Witte (eds) The European Court of Justice and the Autonomy of Member States (Intersentia, 2012), p. 219, at p. 220-227.

${ }^{67}$ The approach differs from Olivier de Schutter's proposal to provide for an external constitutionalisation of the EU's social dimension by the European Charter of Social Rights ('The European Social Charter at the Social Constitution of Europe', in N. Bruun (ed) The European Social Charter and Employment Relations (Hart Publishing, 2017), p. 11. It shares the common aspiration of constitutionalising the Internal Market, but provides a more optimistic assessment of the CFREU in regards to social rights guarantees. Neither is it limited to an observation of the Court's use of the CFREU in its Internal Market case law (see on this N. Nic Shuibhne,
} 


\section{The CFREU: a specifically "social" constitutional condition of the Internal Market}

By giving the Charter has the same status as the Treaties (Article 6 TEU), the Member States have endowed the European Union with a meta-layer of rights enjoying priority over other law. ${ }^{68}$ This emerges from the priority of human dignity as the "real basis of fundamental rights" (Explanatory text to Article 1 CFREU), which does not lend itself to accepting the constitutional protection of markets as such, or economic actors who are not human beings. Under Article 1 CFREU, human dignity "is inviolable (and) must be respected and protected." According to Article 51, the Union and its Member States (when implementing Union law) "shall (...) respect the rights, observe the principles and promote the application thereof". Taken together, these provisions reflect a comprehensive human rights doctrine, as in particular endorsed by the ECtHR, according to which public authorities must respect, protect and promote human rights. ${ }^{69}$ The CFREU thus moves beyond a merely defensive towards a comprehensive conception of human rights.

The CFREU also constitutes a new era of rights constitutionalism in that it views the values of dignity, freedom, equality and solidarity as indivisible, ${ }^{70}$ instead of repeating the traditional compartmentalisations of guarantees into civil, political and socioeconomic rights. ${ }^{71}$ For example, social and labour rights are not quarantined into one chapter only containing principles. They are scattered across the Charter: Article 5 banning slavery and Article 12 guaranteeing the right to join a trade union alongside Article 15 guaranteeing the right to engage in work, can be found under the heading "freedoms", while under the heading "solidarity", rights to information and consultation at the place of work (Article 27), to collective bargaining (Article 28), and to fair working conditions respecting health, safety and dignity, as well as providing for annual leave and limits to the daily working time (Article 31) accompany a straight forward prohibition of child labour (Article 32), and the demand of respect for entitlements to social security benefits and social and housing assistance (Article 34). The CFREU also guaran-

'Fundamental rights and the framework of internal market adjudication: is the Charter making a difference?', in P. Koutrakos (ed) Research Handbook on European Internal Market Law (Edward Elgar, 2017), p. 215).

${ }^{68}$ N. Jääskinnen, 'Fundamental Social Rights in the Charter - Are They Rights? Are They Fundamental? ', in St Peers et al., (eds) The EU Charter of Fundamental Rights: A Commentary, ed. by Steve Peers and others (Hart, 2014), p. 1703-24, L. Lazarus et al., The Evolution of Fundamental Rights, Charters and Case Law (European Parliament, 2011). The contrasting view that economic freedoms and human rights are now co-original (S. de Vries, 'The Protection of Fundamental Rights within Europe's Internal Market after Lisbon - An Endeavour for More Harmony', in S. de Vries et al. (eds), The Protection of Fundamental Rights in the EU After Lisbon (Oxford: Hart, 2013), p. 57), is not convincing, although it is reflected in the ECJ's post Lisbon case law (N. Nic Shuibne, supra n 67, p. 234 in particular).

${ }^{69}$ See L. Lazarus et al (supra n.68), p. 34-37.

${ }^{70}$ C. Dupré, 'Article 1 - Human Dignity', in St. Peers et.al. (eds) The EU Charter of Fundamental Rights. A Commentary, (Oxford: Hart, 2014), p. 2-24.

${ }^{71}$ L. Lazarus et. al. (supra n. 68); A Veldman and S de Vries 'Regulation and enforcement of economic freedoms and social rights: a Thorny Distribution of sovereignty' in: T van den Brink, M. Luchtman and T Scholten (eds) Sovereignty in the Shared Legal Order of the EU (Intersentia 2013), p. 65, at p. 91. 
tees rights for business: for example, Article 15 guarantees the free movement of employees ${ }^{72}$ as well as entrepreneurs, ${ }^{73}$ though this guarantee is limited to natural persons, and does not encompass corporate actors. Their interests are protected by the Treaties' economic freedoms, as well as by Articles 16 and17 CFREU ${ }^{74}$. The right to a private life (Article 7) can be relied upon to ward off overzealous scrutiny of business by competition authorities, ${ }^{75}$ while freedom to express an opinion can be relied upon for defending labelling and other marketing strategies. ${ }^{76}$ While Article 21 (1) protects against discrimination on grounds such as sex, racial and ethnic origin and disability also in working life, ${ }^{77}$ the second paragraph of this provision protects economic actors as well as employees against discrimination on grounds of nationality.

This de-compartmentalisation of rights refutes the alleged hierarchy between the EU economic constitution and its social constitution (epitomised by the objective to approximate working and living conditions while their improvement is being maintained) in favour of the former. In guaranteeing protections of potentially conflicting interests alongside each other, the CFREU confirms that competing interests can and must be reconciled.

Significantly, the CFREU establishes a subtle hierarchy between rights through differentiation in the textual guarantees. Some rights are guaranteed with an inherent restriction, for example indicated by the phrase that they are guaranteed "in accordance with Union law and national law and practices", or "may be regulated by law in so far as is necessary for the general interest". For justifying a limitation of rights with such an inherent limitation, EU or national legislators can rely on any general interest, and do not have to identify a specific Charter right which demands the limitation. By contrast, if a right is guaranteed without an inherent limitation, justifications of restrictions must comply with a higher standard. These differences indicate a structured interrelation of CFREU rights: rights with inherent limitations must cede more ground to rights without those inherent limitations than vice versa.

Even more radically, the subtle hierarchy thus established accords a slight priority to social rights. It guarantees all business-related rights (Articles 16 and 17), which underpin economic freedoms such as freedom of establishment and freedom to provide services, merely in accordance with Union law and national law and practices, or subject to such limitations as are necessary for safeguarding the public interest. These inherent limitations of business rights confirm the Court's case law from before the CFREU was

\footnotetext{
${ }^{72}$ ECJ 4 July 2013, Case C-233/12, Gardella, para. 39.

73 ECJ 30 April 2014 C-390/12 Pfleger para 57.

${ }^{74}$ On the parallel application of freedom of establishment and Article 16 TFEU see ECJ 13 February 2014, Case C-367/12, Sokoll-Seebacher, para. 22, as well as ECJ 21 December 2016 Case C201/15 Anonymi Geniki Etairia Tsimenton Iraklis (AGET Iraklis) v Ypourgos Ergasisa Koinonikis Asfalsis kaiKoinoniikis Allilengysi, discussed below sub IV 2.

${ }^{75}$ ECJ 22 February 2002 C-94/00 Roquette Frères SA para 22-29, confirmed in ECJ 16 May 2017 C-682/15 Berlioz Investment Fund, para 51.

${ }^{76}$ ECJ 17 December 157/14 Neptune Distribution SNC, para 67.

${ }^{77}$ ECJ 1 March 2011 C-239/09 Association Belge des Consommateurs Test-Achats ASBL and Others $v$ Conseil des ministres, para 17.
} 
adopted. ${ }^{78}$ By contrast, some social rights are guaranteed without inherent limitations. This applies, for example, to the right to fair and just working conditions (Article 31) and freedom of association (Article 12), though rights to collective bargaining and action (Article 28) are merely guaranteed in accordance with Union law and national practice. The more favourable position for some social and labour rights in comparison with rights underpinning economic rights mirrors the EU socio-economic model, ${ }^{79}$ which allocates a specifically enhanced position to social integration.

Nevertheless, the CFREU at times guarantees social rights at the same level as economic rights. For example, both the freedom to conduct a business (Article 16) on the one hand and workers' rights to information and consultation (Article 27) and entitlements to social security and social assistance (Article 34 ) on the other hand are guaranteed "in accordance with Union law and national law and practices". Under Article 52 (1) CFREU potential clashes between equally ranked rights are to be resolved through mutual maximisation: ${ }^{80}$ CFREU rights can be limited - subject to the principle of subsidiarity - if this is necessary to protect the rights and freedoms of others. Thus, countervailing rights should be realised to the degree that on balance neither is limited any more than necessary. Its effective implementation depends on the bi-directional application of the proportionality principle. For example, if workers' rights to information and consultation are relied upon to limit freedom to conduct a business, the proportionality principle requires that the restriction of freedom to conduct a business does not go over and above what is necessary to achieve the aim pursued. This may result in limiting the scope for information and consultation of employee representatives. A bidirectional approach requires that the judge scrutinises any such limitations of workers' rights by assessing whether they itgo over and above what is necessary to safeguard freedom to conduct a business.

The Court's case law, if favouring constitutional rights epitomised by economic freedoms, does not always comply with these principles. Restrictions of economic freedoms must safeguard human rights as protected by EU law, ${ }^{81}$ but if Member States rely on human rights for justifying such restrictions, human rights protection is relegated to "the second (justification) stage of analysis". ${ }^{82}$ The bi-directional application of the proportionality principle would correct this imbalance.

\footnotetext{
${ }^{78}$ On this see Schiek (2012), as cited in fn. 10, at p. 225-227.

In summary see D. Schiek, 'The EU's socio-economic model(s) and the crisi(e)s - any perspectives?', in Idem (ed) The EU Economic and Social Model in the Global Crisis, (Farnham: Ashgate, 2013), p. 8-30.

${ }^{80}$ Mutual maximisation is an established principle of constitutional law, inter alia referred to as the optimisation principle (R. Alexy, A Theory of Constitutional Rights (Oxford: Oxford University Press, 2002) and praktische Konkordanz (M. Schladebach, 'Praktische Konkordanz als verfassungsrechtliches Kollisionsprinzip', 53 Der Staat, (2014), p. 263-83

${ }^{81}$ ECJ 18 June 1991 C-260/89 Elliniki Radiophonia Tiléorassi AE and Panellinia Omospondia Syllogon Prossopikou v Dimotiki Etairia Pliroforissis et al. This line of reasoning has been reaffirmed in ECJ 30 April 2014 C-390/12 Pfleger, paragraph 35-36.

${ }^{82} \mathrm{~N}$. Nic Shuibhne, 'The Court of Justice and fundamental Rights: if margin of appreciation is the solution, what is the problem?', in O Mjöll Arnardóttir (ed) Shifting Centres of Gravity in Human Rights Protection (Routledge, 2016), p. 137-64 (p. 148).
} 


\section{What does constitutional conditioning achieve in principle?}

Predominantly, the concept of constitutional conditioning perceives of (social) rights guarantees as shaping economic integration. This contrasts with perspectives that perceive of markets as spheres of original liberty, quasi-governed by forces of nature, preempting any human rights guarantees. Such liberalist perspectives would utilise human rights guarantees for the defence of market processes against "intervention" by regulation, litigation or policies promoting the general interest, including social policy. What appears as "intervention in markets" from those liberalist perspectives is transformed into the constitutional conditioning of markets under the approach proposed here. Markets must be structured and regulated ${ }^{83}$ for the sake of realising the constitutional condition in which they are meant to be.

The Charter of Fundamental Rights supports constitutional conditioning in two ways: first, it establishes subtle hierarchies between rights, which weaken those guarantees that underpin economic freedoms, notably the freedom to conduct a business and the right to property. Some social rights are not so limited, which is an expression of constitutional conditionality in favour of social rights. Secondly, the CFREU demands mutual optimisation of those rights guaranteed at equal level, which defies the priority which has been allocated to economic freedoms by the Court so far.

The next section considers some practical applications, discussing in how far the constitutional conditioning provides a template for the ECJ to revise its case law on economic freedoms.

\section{Practical consequences of constitutional conditioning}

This section revisits the Court's much discussed Laval quartet, ${ }^{84}$ and proceeds to analyse the AGET Iraklis ruling of December $2016 .^{85}$ It demonstrates how the constitutional conditioning parameter offers a set of new hermeneutic principles derived from the CFREU, by which the Court can decide cases where economic freedoms and social rights seem to clash in line with the EU Treaties' commitment to social justice.

\section{Re-drafting Viking and Laval}

The roots of the widely debated ${ }^{86}$ set of cases known as the "Laval quartet" lie in the purported clash between effective collective bargaining and collective industrial action

\footnotetext{
${ }^{83}$ Whether this regulation must be brought about by public actors such as the EU or its Member States, or whether scope must be left for social governance is not the theme of this paper. On this see D. Schiek, supra, fn. 40.

${ }^{84}$ The 'quartet' consists of ECJ 17 December 2007 C-341/05 Laval un Partneri Ltd v Svenska Byggnadsarbetareförbundet, Svenska Byggnadsarbetareförbundets avdelning 1; ECJ 11 December 2007 Case C-438/05 (Viking), ECJ 3 April 2008 Case C-346/06 Rüffert v Land Niedersachsen and ECJ 19 June 2008 Case C-319/06 Commission v. Luxembourg. On some follow up cases, which do not revisit the conflict between collective labour rights and economic freedoms pursued here, see P. Pecinovsky, 'Evolutions in the Social Case Law of the Court of Justice', 7 European Labour Law Journal (2016), p. 294, and D. Schiek et al supra n. * , p. 41-45.

${ }^{85}$ Above fn. 74.

${ }^{86}$ E.g. C. Barnard and S. Deakin, 'European Labour Law after Laval', in Marie-Agne Moreau (ed) Before and After the Economic Crisis. What Implications for the European Social Model,
} 
and the EU economic freedoms; the perception that this conflict can only be resolved by limiting either collective bargaining rights (as social rights) or economic freedoms; and the "solution" offered by the Court affirming the priority of the latter.

In the 1970s, the Court first established that collective agreements may constitute a restriction of today's Article 56 TFEU. ${ }^{87}$ In 1997 the Court found that a Member State refusing to commit police forces to curb social protests against the Internal Market in goods infringed what is today Article 34 TFEU. ${ }^{88}$ From then on, it was easy to predict that the Court would target as an infringement of economic freedoms any collective industrial action that would make the cross-border provision of services or reestablishment of a company less attractive. ${ }^{89}$ However, the rulings in Laval and Viking ${ }^{90}$ further elaborated this past case law, and brought home the implications of applying the economic freedoms largely unfettered by effective protection of social rights in an Internal Market with vastly diverging wage levels.

The Laval case has its origins in a claim lodged by Laval, a Latvian company and owner of the Swedish company Baltic Bydd, ${ }^{91}$ before Swedish courts. Laval challenged the legality of a blockade and other modes of industrial action staged by BYGNADS, the Swedish builders' trade union with the aim of concluding a collective agreement between BYGNADS and the Swedish company which would guarantee that pay was governed by the same framework for all workers working side by side on the same building site. Baltic Bydd used workers posted by its Latvian owners, and did not intend to pay these Latvian workers at levels usual in Sweden. There are some indications that the case was staged from Sweden to break the hold of BYGNADS on wages in the building sector. ${ }^{92}$ The Viking case emerged from an employer's claim against the Finish Seamen's Union (FSU) and the International Transport Workers Federation (ITWF), raised before a British court because ITWF is registered in London. The employer had re-registered a vessel under the Estonian flag, with the aim of enhancing the profitability of a ferry between Tallin and Helsinki by lowering wages paid to seafarers. The FSU threatened collective action, and the ITWF issued a circulaire to its members asking them not to enter into negotiations with Viking Line ABP while the industrial dispute was ongoing. The combination of these activities had effectively hindered the employer from lowering wages

(Cheltenham: Edward Elgar, 2011), p. 252-69. M. Freedland and J. Prassl (eds), Viking, Laval and Beyond, (Oxford: Hart, 2015), A. Supiot, 'Under Eastern Eyes', 73 New Left Review, (2013) p. 29; for more details and further references see D. Schiek, supra n 10, p. 133-135, 164-168, 206-207), D. Schiek et. al., supra $n *$, p. 31-32, 36, 41.

${ }^{87}$ ECJ 12 December 1974 Case 36/74 B.N.O. Walrave and L.J.N. Koch v Association Union cycliste internationale, Koninklijke Nederlandsche Wielren Unie and Federación Española Ciclismo, paragraph 18.

${ }^{88}$ ECJ 9 December 1997 Case C-265/95 COM v France (Strawberries).

${ }^{89}$ G. Orlandini, 'The free movement of goods as a possible "Community" limitation on industrial conflict', 6 European Law Journal (2000), p. 341

${ }^{90}$ Both above fn. 84.

${ }^{91}$ One could doubt whether the transnational element in this case was sufficient for triggering Article 56 TFEU, see S. Deakin, 'Regulatory Competition after Laval', 10 Cambridge Yearbook of European Legal Studies, (2007-2008), p. 581.

92 See the careful analysis by Woolfson and Sommers, 'European Mobility in Construction' (2006) 12 European Journal of Industrial Relations 54. 
until Estonia joined the EU. At this point, the employer decided to litigate, relying on its EU economic freedoms to achieve the aim it failed to accomplish through negotiation.

In both cases the Court held that the right to collective bargaining and collective industrial action was guaranteed under EU law in principle, and that collective industrial action aiming to improve working conditions could in principle justify the restriction of economic freedoms by efficient collective industrial action. However, collective industrial action would only be proportionate to achieving that aim if it was absolutely necessary for this purpose. For the Viking case, that judgment was left to the national court. However, the ECJ held that boycotts and strikes would only be legal if necessary to protect the Finnish workers' posts or working conditions, and that the employers' legally non-binding commitment to refrain from dismissing the Finnish crew would render the action unnecessary. In the Laval case, the Court found the industrial action of a Swedish trade union aiming to force an employer posting Latvian workers to sign an association agreement with them to be unjustifiable. Much of the case turned on the interpretation of Directive 96/71 ${ }^{93}$, which, however, was interpreted as mere specification of Article 56 TFEU on freedom to provide services. That provision, the Court held, prevented the trade union from fighting for a higher level of protection than was guaranteed by EU legislation and required that the trade union disclose its red lines before any negotiation even started. There was no margin of appreciation for the trade unions in justifying their action, which would ensure that economic freedoms and fundamental constitutional rights were adequately balanced, resulting in critical assessment by international human rights bodies.

Under the principles of a constitutionally conditioned internal market this line of case law is untenable. This derives from the specific hierarchy established by the Charter between collective labour rights and constitutional equivalents of economic freedoms.

Collective labour rights such as the right of freedom of association (Article 12) and the right to collective bargaining and collective industrial action (Article 28) are inextricably linked, although guaranteed in discrete provisions of the Charter. This is particularly well established by the ECtHR case law on Article 11 ECHR, which clarifies that a guarantee of freedom of association for trade unions includes constitutional protection of collective bargaining and collective industrial action. ${ }^{95}$ To maintain congruence of the

\footnotetext{
${ }^{93}$ Directive 96/71/EC of 16 December 1996 concerning the posting of workers in the framework of the provision of services, [1996] OJ L 018, 21.01.1997

${ }^{94}$ The ILO Committee of Experts on the Application of Conventions and Recommendations (CEACR) expressed concern that Swedish trade unions are barred from taking action in support of their members who work for employers posting them (ILO CEACR, Report 2013, 178); and the potentially deterrent effect of high damages being awarded to employers in cases of infringement of their rights under Article 49 TFEU by UK courts led to a complaint by the Union and subsequent mentioning of the affair in the CEACR report for the ILO (ILO Session 2010, Report III Part I A, p 209 [http://www.ilo.org/wcmsp5/groups/public/---ed_norm/--relconf/documents/meetingdocument/wcms 123424.pdf].)

${ }^{95}$ ECtHR 12 November 2008 Case No. 34503/97 Demir and Baykara v Turkey and ECtHR 21 April 2009 Case No. 68959/01, Enerji Yapi-Yol Sen v Turkey. The slightly more restrictive ruling ECtHR 8.4.2014 App No 31045/10 RMT v United Kingdom still maintained the rule that Article 11 ECHR guarantees the right to collective bargaining and collective industrial action, though it did not hold the restrictive UK legislation on balloting incompatible with Article 11 ECHR.
} 
European Convention of Human Rights and the Charter as demanded by Article 52 (3) of the Charter, Article 12 must be read - in line with this ECtHR case law - as embodying rights to collective bargaining and collective industrial action. ${ }^{96}$ Article 12 thus forms the basis for collective labour rights, while Articles 27 and 28 provide specifications. Accordingly, collective labour rights are guaranteed as rights that can be restricted only with reference to Article 52 of the Charter, i.e. by in order to protect the general interest as well as competing rights. The reference to national traditions in Article 28 retains its relevance in that the Union guarantees must account for the diversity of national traditions in industrial relations. Any limitation of the rights to collective bargaining and collective industrial action under Article 52 must not deprive these rights of their essence. Further, the limitation must be proportionate to achieve its aim. Hence, the question must be asked whether curtailing collective bargaining and industrial action is unavoidable for enabling the exercise of the economic freedoms.

The economic freedoms of corporations can be underpinned by Article 16 of the Charter, and are thus only guaranteed in accordance with Union law and national law. Since the Charter is part of Union law, Article 16 rights are only guaranteed in line with Article 12 rights. Accordingly, business in the EU must occasionally expect to be subjected to industrial action as well as to be bound by collective bargaining agreements.

To comply with the Charter, the Court would have to assume that collective industrial action is nothing unusual. Accordingly, strikes or blockades would not automatically qualify as restrictions of economic freedoms. If a Swedish business operating in Sweden that is evading its obligations under collective labour agreements is subjected to collective industrial action, a Latvian business evading that same obligation would have to expect the same treatment. Thus, the strike action suffered by Laval un Partneri would not constitute any specific detriment to transnational business, and hence no restriction of freedom to provide services. Similarly, since trade unions oppose companies moving to escape the binding force of a collective agreement, collective industrial action undertaken with that purpose is admissible in principle. ${ }^{97}$ The same activity directed against an employer that aims to establish itself in another EU Member State can hardly be viewed as restriction of freedom of establishment.

Under specific circumstances, collective industrial action may still qualify as a restriction of economic freedoms. For example, if trade unions would engage in collective industrial action with the aim of preventing individual persons from exercising their free movement rights - whether as workers or service providers - this would clearly constitute a restriction. Similarly, if trade unions would specifically target foreign companies avoiding collective agreements by exercising their free movement rights, but fail to target national companies avoiding collective agreements in other ways, this might also

\footnotetext{
${ }^{96}$ As here Veldman, A. 'The Protection of the Fundamental Right to Strike within the Context of the European Internal Market: Implications of the Forthcoming Accession of the EU to the ECHR' (2013) Utrecht Law Review, 9(1), pp. 104-117, see also C. Barnard, 'Article 28: Right of Collective Bargaining and Action', in St Peers et al (eds) The EU Charter of Fundamental Rights - A Commentary, (Oxford: Hart, 2014), p. 773-94, implied at marginal note 12, and F. Dorssemont, 'Article 12 (1) Freedom of Association', ibid, p. 341-66, marginal note 14 (suggesting that "the right to take collective action is less stringent under the Charter" than under the ECHR).

${ }^{97}$ This has long been recognised in national law, e.g. for Germany by Bundesarbeitsgericht 10.12.2002 case 1 AZR 96/02.
} 
constitute a restriction. In both cases, the Court would still have to consider potential justifications for collective industrial action by using the bidirectional proportionality test developed earlier. ${ }^{98}$ The Court would have to consider whether limiting options to take collective industrial action is necessary to protect the freedom to provide business across a border, keeping in mind that Article 16 of the Charter is less robust than Article 12.

The concept of the constitutionally conditioned internal market provides a new answer to the conundrum posed by the Laval and Viking conflict; an answer that is also in line with international guarantees of collective labour rights, and that avoids the challenges made before these committees.

\section{The AGET Iraklion case: protecting the freedom to conduct a business versus workers' participation in collective redundancies}

While the Court has not yet revisited its case law on the conflict between collective labour rights and economic freedoms, the AGET Iraklis ${ }^{100}$ case offered an opportunity for the Court to reconsider its contested case law on Article 16 CFREU, and thus provides another example of the potential use of constitutional conditioning.

The case concerned collective redundancies in Greece, and more particularly the viability of national legislation requiring a ministerial authorisation of any collective redundancy in the absence of an agreement with the workers' representatives. The case, allocated to the Grand Chamber, had a certain political salience, since it was referred by the Greek Council of State and related to legislation which has been part of the negotiations of the Memorandum of Understanding (MoU) of August 2015 as well as a subject of debate by the Expert Group established in order to review labour law reforms which Greece undertook under a previous MoU. ${ }^{101}$

Directive $98 / 59^{102}$ on collective redundancies neither requires nor precludes national legislation demanding consent of the works council or the ministry before a collective redundancy can become effective. ${ }^{103}$ While the widely discussed Alemo Herron case

\footnotetext{
${ }^{98}$ See above text to $\mathrm{nn}$ 80-83.

99 See M. Rocca, 'Enemy at the (Flood) Gates. EU Exceptionalism in Recent Tensions with the International Protection of Social Rights', 7 European Labour Law Journal (2016), 52-80; on the relevance to rely on the CFREU (interpreted in the light of international guarantees of social and labour rights) see M. Schlachter, 'Stärkung sozialer Rechte durch Grundrechtsschutz im europäischen Mehrebenensystem?', 54 Europarecht (2016), p. 478.

${ }^{100}$ Above fn.74; see also M. Markakis, 'Can Governments Control Mass Layoffs by Employers? Economic Freedoms vs Labour Rights in Case C-201/15 AGET Iraklis', in this edition of EuConst.

${ }^{101}$ The Memorandum of understanding can be accessed here: http://ec.europa.eu/economy finance/assistance eu ms/greek loan facility/pdf/01 mou 201 50811 en.pdf ; the report of the Expert Group was delivered in September 2016: http://www.capital.gr/Content/RelatedFiles/68/6898c2f55b6f4348828383f331261304.pdf ); see also the opinion by AG Wahl in the case, who supports his final finding with the necessity to "reduce all factors which deter new undertakings from investing" in "times of crisis" (paragraph 80)

Council Directive 98/59/EC of 20 July 1998 on the approximation of the laws of the Member States relating to collective redundancies (OJ 1998 L 225/16, corrigendum OJ 2007 L 59/84) 103

Paragraph 44 of the judgment, and 49 of AG Wahl's opinion.
} 
concerned the degree to which the UK legislator had to consider Article 16 CFREU while implementing Article 3 of Directive 2001/23 on transfers of undertakings, ${ }^{104}$ the Greek legislation at stake in AGET Iraklis went over and above the requirements of Directive 98/59. To the extent that it was not required, the Court found it did not implement Directive $98 / 59$. Thus, in order to be able to use the CFREU as a standard, the Court needed to establish that the Greek legislation restricted an economic freedom, in this case Article 49 TFEU. ${ }^{105}$

The Court followed AG Wahl in finding that the national legislation restricted freedom of establishment, that justification of the national measure would also have to satisfy the requirements of Article 16 CFREU, and that the specific restriction of Article 49 TFEU (read in the light of Article 16 CFREU) was not justifiable.

In deciding whether there was indeed a restriction of freedom of establishment, the Court relied on its former case law that minimises the level of transnational activity a business needs to engage in to gain the protection of the EU economic freedoms. Going beyond such reasoning, AG Wahl opened his opinion with the statement "The European Union is based on a free market economy, which implies that undertakings must have the freedom to conduct their business as they see fit". The Court factually endorsed that reasoning without expressly referring to it: It stated that freedom of establishment not only constituted a positive right to establish in another Member State, but also a negative freedom to close down a subsidiary in that other Member State or reduce its activities. ${ }^{107}$ Also, the Court qualified taking on and dismissing employees as a decisive element of the freedom of establishment. ${ }^{108}$ Under this logic, any legislation limiting the employers' freedom to dismiss employees would constitute a restriction of Article 49 TFEU, which would contrast with the Court's case law up to then on economic freedoms, according to which employment protection would only constitute a restriction of the free movement of workers if it specifically deterred an employee from moving to another country ${ }^{109}$ As a result, a Greek company struggling to comply with Greek employment protection law was protected by Article 49 TFEU on the basis that $89 \%$ of its shares were held by a French multinational group of companies. ${ }^{110}$

Both the Court and its AG also refer to Charter rights at the justification stage. While Article 16 of the Charter had already been used to extend the scope of freedom of establishment, it made another appearance at this stage, as Member States must protect

\footnotetext{
${ }^{104}$ ECJ 18 July 2913 Case C-426/11 Alemo Herron and Others v Parkwood Leisure Ltd, see S. Weatherill, 'Use and Abuse of the EU's Charter of Fundamental Rights: on the improper veneration of freedom of contract' 10 European Review of Contract Law (2014) p. 157; J. Prassl, 'Freedom of Contract as a General Principle of EU Law? Transfers of Undertakings and the Protection of Employer Rights in EU Labour Law' 42 Industrial Law Journal (2013) p. 434.

${ }^{105}$ Article 63 TFEU was also relied upon, but any impact on investment would only be ancillary to the impact on freedom of establishment and conducting a business (paragraphs 58-60 of the ruling).

${ }^{106}$ See text to $\mathrm{nn} 53$ and 54.

${ }^{107}$ Paragraph 53 of the judgment, referring to para 65 of the AG opinion.

${ }^{108}$ Paragraph 54, 55.

${ }^{109}$ ECJ 27 January 2000 C-190/98 Volker Graf v Filzmoser Maschinenbau GmbH, paragraphs 2425.

${ }^{110}$ Paragraph 47 of the judgment.
} 
Charter guarantees of business freedom while limiting TFEU economic freedom. Article 16 CFREU was read in a strictly libertarian way as the "freedom to exercise an economic or commercial activity, freedom of contract and free competition", ${ }^{111}$ and thus ran parallel to an unconditioned freedom of establishment. Only social rights are referred to at the justification level.

AG Wahl initially considered that, at the justification level, a balance needs to be struck between business freedom and other Charter rights. ${ }^{112}$ He found that Article 27 of the Charter (workers' rights to consultation and information) must be given specific expression in EU and national law, which Directive $98 / 59$ does not provide. Thus Article 27 does not provide any protection here. Neither does Article 30, which guarantees the protection of workers in cases of unjustified dismissal, protect against economically motivated redundancies in Wahl's view. Accordingly, he found no need to balance that provision with business freedom.

The Court made ample reference to the EU's social objectives, ${ }^{113}$ which feed into aspects of general interest which in principle may justify employment protection legislation (e.g. protection of works, or the maintenance of employment. ${ }^{114}$ The Court briefly mentioned Article 30 of the Charter in the context of proportionality. ${ }^{115}$ However, the Court only discussed whether the framework for collective redundancies is sufficiently transparent and predictable to avoid violation of Article 16 CFREU, and did not refer to Article 30 CFREU. ${ }^{116}$ As a result, a legislative prohibition on effecting collective redundancies was viewed as disproportionate. In effect, Article 30 CFREU was thus not given substantive weight, and Article 27 CFREU was not mentioned. The reference to social policy objectives without linking them to their fundamental rights basis inevitably left the freedom of establishment, bolstered by Article 16 CFREU as a fundamental right, as the stronger, and victorious, principle. The "commendable" ${ }^{117}$ lengthy discussion of social policy objectives in effect legitimises that weakness with its juxtaposition of social policy and economic integration.

Taking due consideration of the constitutionally conditioned Internal Market, the argument would need to proceed along different lines. Since the European Union is based on a social market economy (Article 3 TEU), and not merely on a free market economy, cross-border cooperation based on the economic freedoms is constitutionally conditioned. Accordingly, the freedom of establishment as guaranteed by the Treaties would be conditioned by legislation (at EU or national level) protecting against dismissal and thus specifying Article 30 of the Charter, and ensuring that workers are consulted and informed (specifying Article 27 of the Charter). While the Court admits that Article 16 'recognises' the freedom to conduct a business in accordance with Union law and national law and practice, without guaranteeing it unconditionally, its refusal to substan-

\footnotetext{
${ }^{111}$ Paragraph 67 of the judgment, paragraph 49 of the opinion, references omitted.

${ }^{112}$ Paragraph 57 of his opinion.

${ }^{113}$ Paragraphs 71-78.

${ }^{114}$ Paragraph 73-75.

${ }^{115}$ Paragraph 89.

${ }^{116}$ Paragraphs 96-103.

${ }^{117}$ Markakis, in this volume (fn. 100).
} 
tively engage with Article 30 and 27 as fundamental rights results in the de-recognition of their guarantees as conditions for the Internal Market.

Article 30 of the Charter in particular is not devoid of content: Following the Explanations to the Charter, it must be interpreted with reference to Article 24 of the European Social Charter, according to which dismissals may be based on the operational requirements of the business, but mere economic difficulties can arguably not justify collective redundancy. ${ }^{118}$ Under Article 30 of the Charter, protection against dismissals is provided as guaranteed by Union law as well as national law and practice. Union law would comprise secondary legislation (which does not limit the freedom to dismiss employees), as well as Charter rights, including the right to engage in work (Article 15). National laws and practice include the Greek legislation which considers a collective dismissal unjustified in the absence of either agreement with the workers' representatives or ministerial authorisation. That national law also sets the frame in which the right to business is guaranteed, alongside employees' right to engage in work and their right to protection in the event of unjustified dismissal. This leads to a different interpretation of Article 49 TFEU than that chosen by the Court. Since Article 49 TFEU is conditioned by the existing legislation in the field (as is, implicitly, Article 16 of the Charter), the mere application of employment protection legislation would not even constitute a restriction of this guarantee. The proportionality test would only be necessary if legislation either treated international employers differently from Greek employers, or factually had a more detrimental effect on international employers than on Greek employers.

Overall, the concept of constitutionally conditioned economic integration allows a reasoned critique of overly libertarian case law and, if applied by the Court, would really make a difference in certain pivotal cases.

\section{Conclusion}

This article has developed the constitutionally conditioned Internal Market as a novel approach to EU constitutional law which offers the ECJ an alternative to prioritising EU economic freedoms over social rights in its future case law.

The concept of a constitutionally conditioned Internal Market challenges the dogma that the EU's economic and social constitutions necessarily stand in juxtaposition to each other. Drawing on the priority of human dignity and a modern human rights concept as embodied in the Charter, this article concludes that the Internal Market is not "intervened in" by protecting social and labour rights, but that it is rather conditioned by adequate respect for, and protection and promotion of, these rights. This concept underlines the necessity for policy change, and at the same time develops innovative ways for warding off challenges posed by socio-economic standards established by legislation or collective agreement.

\footnotetext{
${ }^{118} \mathrm{M}$. Schmitt derives from ECSR case law that only economic difficulties, not a mere change of strategy, can justify collective redundancy, and points to a pending case where the legitimacy of collective dismissal in order to increase profit is questioned ('Article 24 The Right to Protection in Cases of Termination of Employment' in N Bruun (ed) The European Social Charter and Employment Relation (Bloomsbury, 2017) p. 412-438).
} 
As stressed above, the concept of a constitutionally conditioned internal market comprises the often rehearsed suggestion that in cases of conflict between economic freedoms and social and labour rights, a bi-directional proportionality test has to be conducted. ${ }^{119}$ The Court should not only ask whether the social right protected by legislation or collective bargaining disproportionately limits the economic freedom, but also consider whether depriving citizens of the specific social or labour right is necessary to safeguard the relevant economic freedom. Similarly, if the aim is merely to redraw the boundaries of the ECJ to control national law (i.e. to move the balance in favour of the Member States), the doctrinal proposal to "restrict the restriction" ${ }^{120}$ can achieve some progress in that the Court would exercise less control over national law.

However, these proposals do not raise the question of whether the primacy of economic freedoms over social and labour rights is fundamentally wrong or not. By contrast, the constitutionally conditioned Internal Market establishes that rights, including those derived from the EU's social constitution, shape rather than restrict EU economic freedoms, effectively challenging the dominance of the latter. Using the example of social and labour rights, the article has demonstrated how these rights can be treated as a condition under which the Internal Market can function, and the economic freedoms implemented. This concept allows some scope for economic freedoms and competition law in so far as these instruments are suitable to overcome national and regional barriers to economic integration. Constitutionally conditioned, economic freedoms are not just drawn back in favour of Member States or public legislators. Instead they are redrafted to accommodate, and incorporate the civilisation of raw market power by accommodating social concerns. This way, the judicial application of Internal Market law can encourage and invigorate discourse on the best shape for the transnational market and society to which the EU aspires.

Just developing these arguments is not, however, sufficient to exchange the "free market economy" - conjured by AG Wahl as the EU's economic constitution, - for the constitutionally conditioned social market economy - as demanded by the Treaties and the Charter of Fundamental Rights for the EU. As the Court must be viewed as a political actor, the preconditions for changes in its case law presuppose the development of a wider discourse on the adequate constitutional frame for the future of EU integration. Such discourse at the European level by a variety of actors would enable the rediscovery of social integration as an endeavour underlying the EU project. The present geopolitical situation provides the leverage to develop and strengthen this discourse. While "Brexit" is based on internal UK politics, the fears of increasing EU economic integration suffered by those who feel left behind exist throughout the EU. Those same fears are used to justify a retreat towards protecting work for nationals, and to limit economic integration beyond the EU. The EU model of socio-economic integration offers, in principle, an alternative to economic integration without any consideration for social concerns. If the $\mathrm{EU}$ is to prevent its own disintegration and safeguard its geo-political position, a retreat from its project of integration through rights does not seem a promising avenue. Instead, rebalancing the integration project in a truly European way would

\footnotetext{
${ }^{119}$ See Nic Shuibhne, supra fn 67, at 230-231, with further references.

${ }^{120}$ C. Barnard, 'Restricting Restrictions: Lessons for the EU from the US?' 68 Cambridge Law Journal (2009), p. 575, S. Garben, supra fn 1, p. 35.
} 
require strengthening the social element through reinforcing social rights. It seems an appropriate time to engage in this discourse, for example through critical engagement with the European Pillar of Social Rights and its implementation. 